\title{
Current changes of sandy seashore of Lithuania within the impact of natural and anthropogenic processes
}

\author{
Vytautas Dubra, Institute of Maritime and Cultural Landcapes of the Klaipeda University, Lithuania, \\ vdubra@gmail.com \\ Petras Grecevičius, Department of Lanscape Architecture and Territorry Planning of the Klaipeda \\ University, Lithuania, petras.grecevicius@ku.It \\ Juozas Dubra, Maritime Institute of the Klaipeda University, Lithuania, juozas.dubra@gmail.com
}

\begin{abstract}
The major part of the South Eastern Baltic sandy seashore is influenced by erosion and recession of varying intensity. Total Lithuanian coastline length doesn't exceed $100 \mathrm{~km}$ there, but this area is prominent for its fine sand beaches and costal protective dunes. The main goal of the present research was to define the trends of coastal dynamic processes of Lithuanian seashore area within the long-term impact of natural processes and human action.

The coastline changes have been estimated by means of aerial photography and detailed field geodetic measurements within the period since 1999 with the supplementary addition of historical data backing to the end of $19^{\text {th }}$ century. Annual rates of dune base line position were calculated for the mentioned period. The history of coastal protection development was analysed, as well. Application of aerial photography and historical field topography data gives us the possibility to find some peculiarities in coastal changes. The identification of the eroded and relatively stable areas is very important for spatial planning, coastal protection and other activities, related to the coast that bears man-made coastal protective dunes, including ones on the Curonian Spit.
\end{abstract}

Keywords: sandy seashore, Lithuania, Curonian Spit, coastal protective dune, erosion, annual rate.

\section{Introduction}

The South-East coast of the Baltic Sea that borders the Lithuanian territory is mostly covered with sand (Fig. 1). Only within a short coastal strip (4,5 kilometers) of it, moraine cliffs are present. The coastal zone is open to storms, which are resulting into perfect fetch conditions for the development of waves. Therefore a constant care of the seacoast is of obvious necessity in order to save more or less stable coastline. During the last 25 years the mean sea level of the Baltic Sea near Klaipeda has risen by $10 \mathrm{~cm}$ and is still raising (Dubra \& Grecevičius, 2006). Thus the abrasion of the seacoast might become much more active in future.

Since the very beginning of the $19^{\text {th }}$ century attempts to stabilise coastline shifting are undertaken (Dubra, 2006). In order to keep dwelling areas safe from burying with sand, a sandy protective dune was constructed along the entire Lithuanian seashore line. In 1834, when jetties of the Port of Klaipeda were reinforced and prolonged, the seacoast was stabilised to the north from the port entrance and it was moved seawards for about 300 
meters. In 1888-1890 the construction of a pier-type sea port near Palanga was implemented. Under the pier a waterproof groyne was erected for prevention of the wave action. This resulted to rapid sand accumulation within the groyne impact area. After several years due to exploitation difficulties shipping activities were closed in Palanga and the promenade pier began to serve the needs of holiday makers only. Due to intensive sand accumulation processes the coast moved seawards by 450 meters in 1888-1947 (Karwowski, 1913; Žilinskas, 2001). Subsequently, a prominence of the shore occurred that made up the area of 80 hectares and the beach near Palanga become over a hundred meters wide. In 1925, about 12 kilometers northwards from Palanga, jetties of the Port of Šventoji were constructed. They enabled the stabilisation of the seacoast and moved it over 150 meters seawards, especially there to the south from the hydrotechnical structures, which stipulated accumulation of very fine and fine sand.

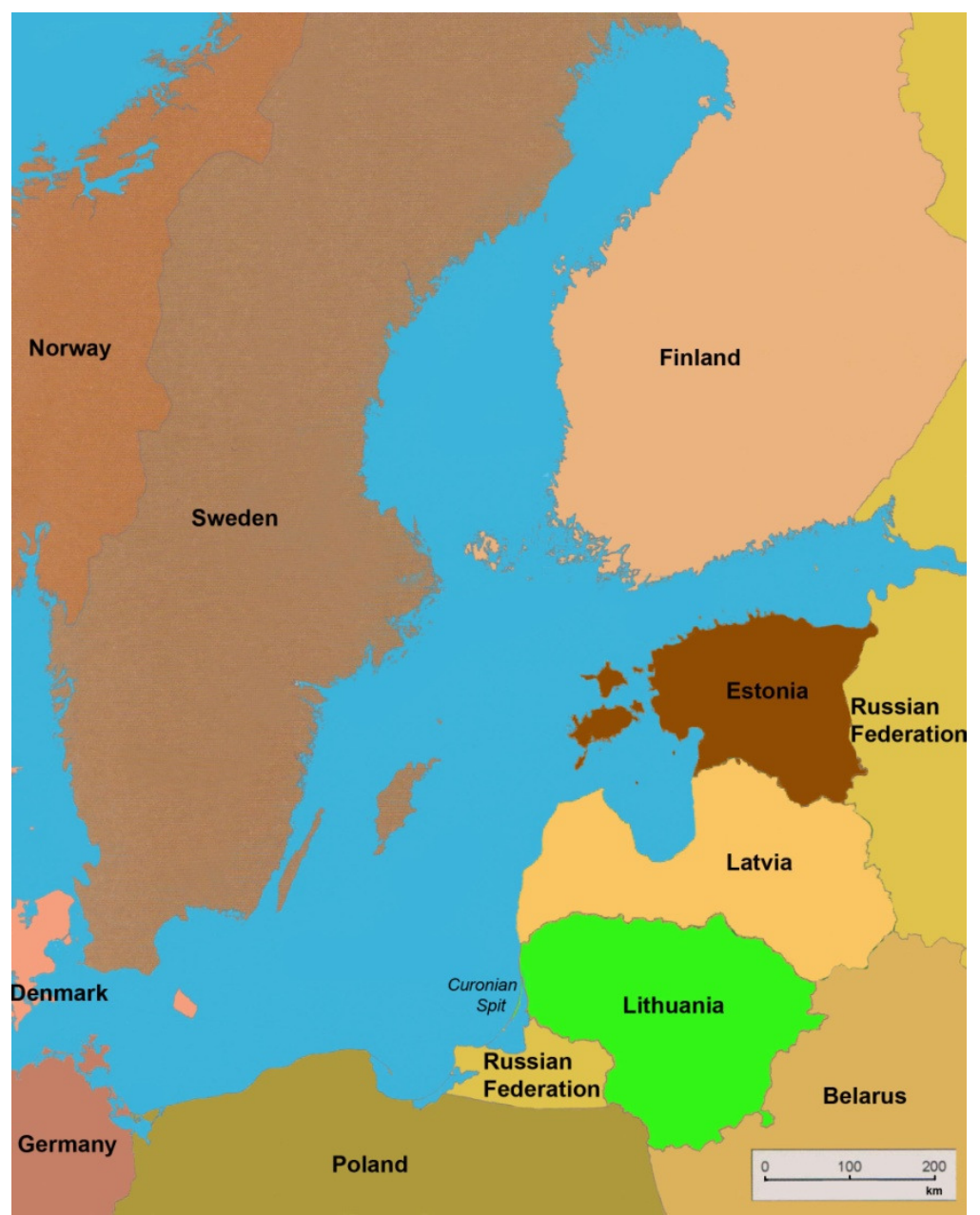

Fig. 1. Study area - Lithuanian seashore

The sandy matter is the most significant source of sedimentary transport for seashore beaches of the Eastern Baltic Sea. Installation of new coast-related or coast protection hydrotechnical structures seriously affect the budget of drifting matter. In 1960-1964 on the basis of data of the long-term research on the Baltic Sea near the Port of Klaipeda, R. Knaps found out that the near shore streams that carry sand had the northward direction and that the amount of sand was about 250-500 thousand cubic meters (Knaps 1966). It was detected by using marked sand and automatic current recorders. Later V. Gudelis stated that the yearly amount of transported sand was 300,000 cubic meters (Gudelis 1998). It is 
important to mention that the hydrotechnical structures mentioned above stabilise the shore well only in calm periods. During strong gales and hurricanes a very high sea water level causes precarious situations. Strong waves, currents and wind result in the deflation processes on the shore (Žilinskas, 2001). The recent investigations of the Lithuanian mainland coastal area show the decreased volume of the sediment transport. The studies of Žilinskas et al. (2003) stated that the budget of mainland coastal surface sediments during the period of 1993-2003 was negative. The average annual loss of sediments from the Lithuanian mainland coast is about 48,000 cubic meters of sand. According to Kriaučiūnienè et al. (2006), the Lithuanian mainland beaches could accumulate 100,000 cubic meters of sediments a year.

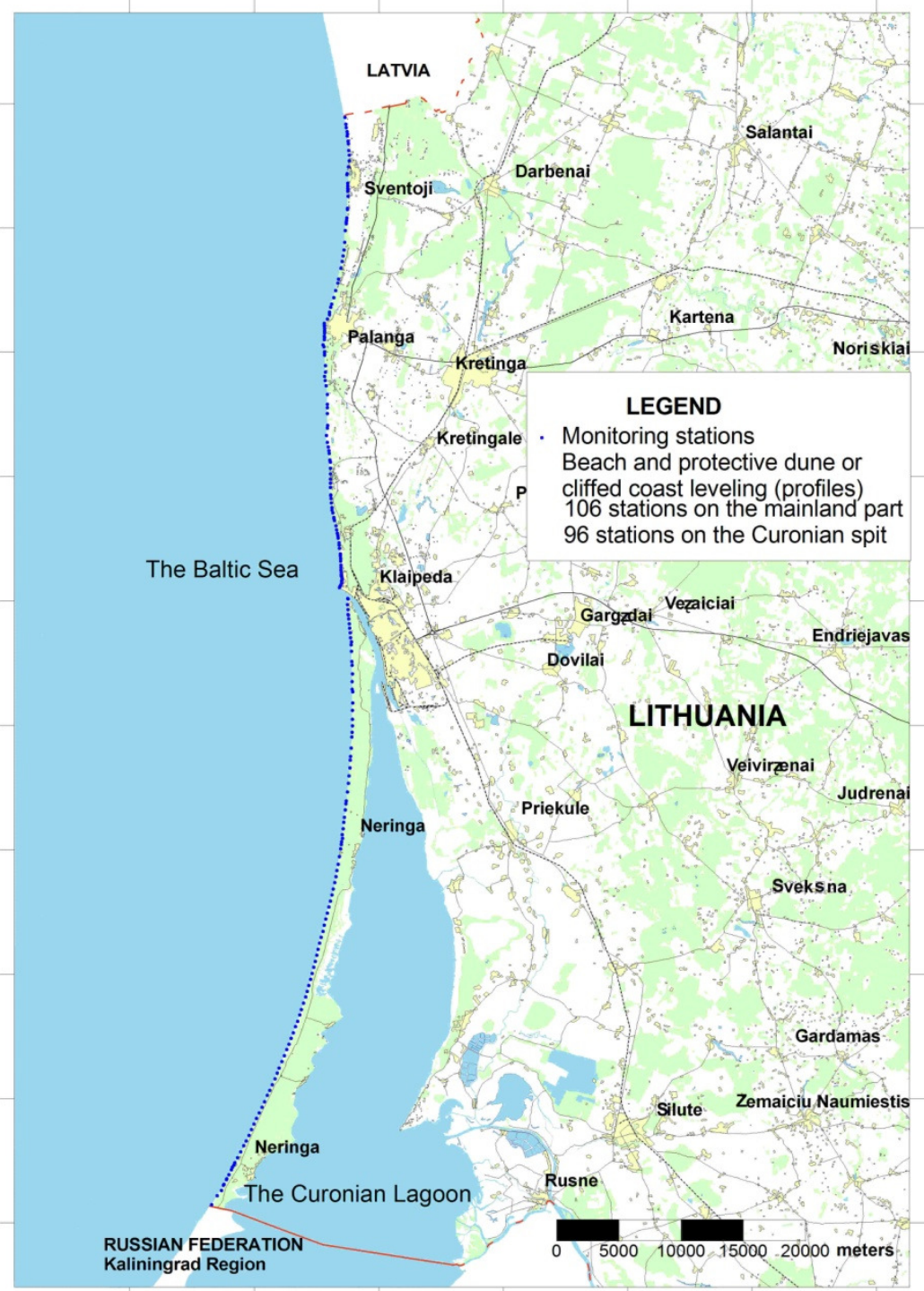

Fig. 2. Study area monitoring network

\section{Material and methods}

For many years the Lithuanian sandy seacoast was investigated by scientific workers of various fields: M. Daujotas (1958), R. Knaps (1966), V. Gudelis (1998), G. Žilinskas et.al. $(2000,2003)$ and others, but systematic measurements of the coast and its changes were not presented. 
The investigations discussed here were begun in early 2000. First of all the estimation of the impact on the seacoast caused by Anatoly was made. Surveys of the seacoast are carried once a year and additionally after very considerable damages to the coast caused by different reasons.

As we failed to find data of systematical seacoast investigations, everything had to be done from the beginning. Thus since 2000 a network of profiles was established instead of that episodic observations that had been made before. Every 200 meters were chosen in the areas frequently visited by people or destroyed places. In other places the survey was done every 500-1000 meters. Now the network is expanded by adding new temporal or permanent profiles in cases of new coastal abrasion occur. At present the monitoring of the coastal dynamics is performed in 129 profiles on the mainland part of the Baltic coast and in 108 ones on the seashore of the Curonian Spit (Fig. 2). Dune parameters are the subjects of geodetic observation methods. These include morphometric data accessed by the means of DGPS equipment and supported with WAAS/EGNOS functions and altimeter. More detailed observations and profiling are performed with the help of total geodetic station and tapemeasures. Morphometric observations of the Baltic Sea coastal zone of Lithuania are performed by the authors of the paper twice a year in spring and autumn as well as after every extreme storm surge occasion. Yearbooks were the source for the collection of the historical data in order to extend data series. Historical data on the beach devastation rate originates from the monograph of V. Gudelis (1998). Experimental investigations from the Palanga promenade pier are performed in order to calculate sediment transport budget near the coast zone. Sea level readings are obtained by sea level gauge in Klaipeda. At least twice-a-day level data was put into statistical analysis.

\section{Results}

One of the most important factors affecting the coastal processes is the sea level. Changes of sea level in the Baltic Sea vary due to winds mainly. Occurrence of the latest known sea levels exceeding $+140 \mathrm{~cm}(\mathrm{BE})$ is presented in Table 1 .

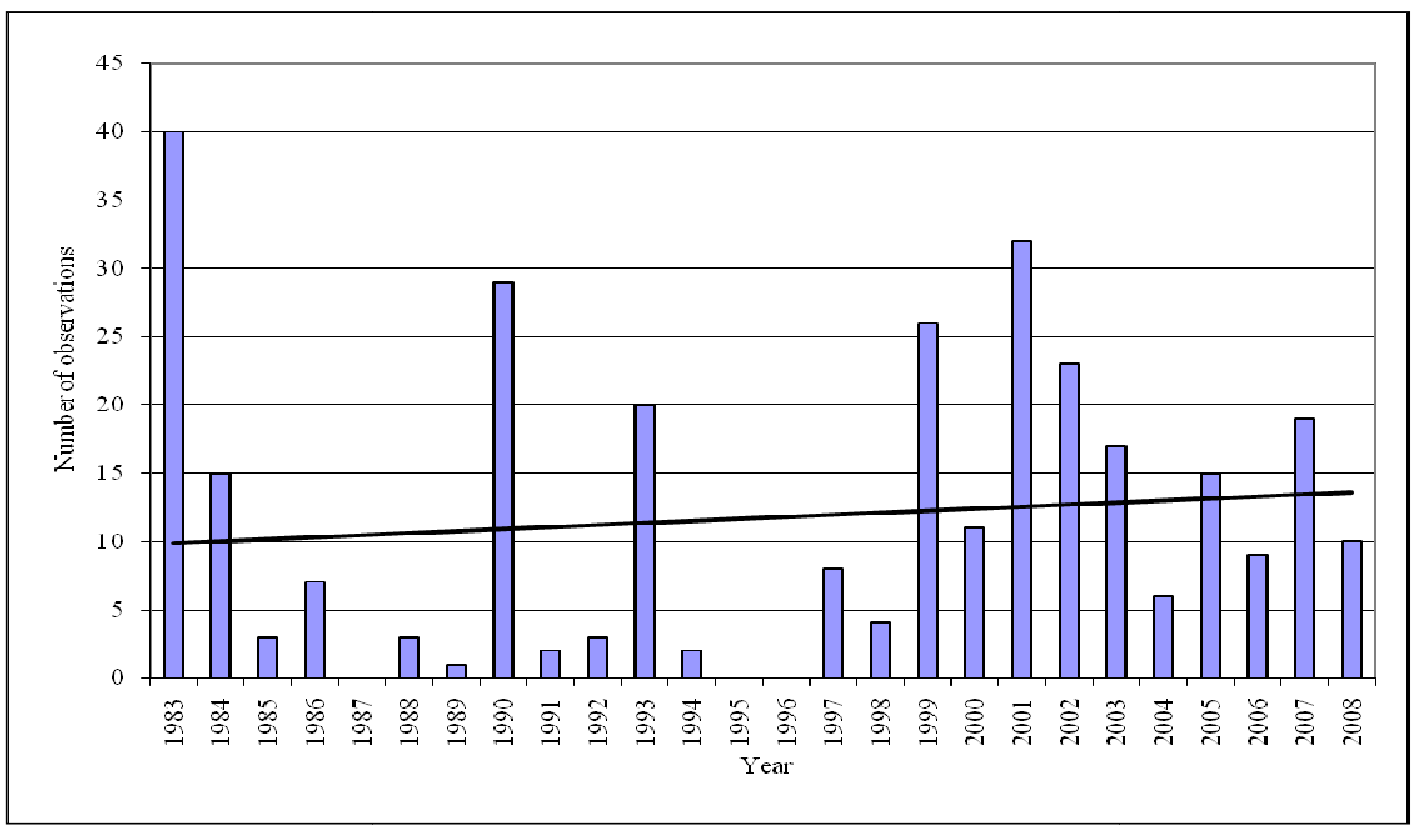


Fig. 3. Trendline of the annual number of three-hour wind observation cases with gales when the velocity exceeded $24 \mathrm{~m} / \mathrm{s}$ at Klaipeda

Table 1. Occurrence of the latest known sea levels exceeding $+140 \mathrm{~cm}$ (Baltic Elevation)

\begin{tabular}{|l|l|l|l|l|l|l|l|l|}
\hline Year & 1849 & 1967 & 1983 & 1999 & 2005 & 2007 & $>2009$ \\
\hline $\begin{array}{l}\text { Period in years since the } \\
\text { precesting }\end{array}$ & No data & 118 & 16 & 16 & 6 & 2 & $>2$ \\
\hline
\end{tabular}

During the previous decade the Lithuanian seashore suffered the worst stress on December 4, 1999 during the rage of the hurricane Anatoly. The shore was almost abraded. In the port of Klaipeda the second high ( $165 \mathrm{~cm}$ above zero, while the highest was $186 \mathrm{~cm}$ in 1967) sea level rise was recorded within the period of 200 years. January 8-9 in 2005 a bit weaker in strength and by 2.5 times shorter in duration strong storm Gudrun known also as Erwin occurred. During this hurricane the third high sea level rise was observed in Klaipeda. In 2002 January 29 the wind blew $32 \mathrm{~m} / \mathrm{s}$ and the sea level raised up to $137 \mathrm{~cm}$ gauge (the eighth highest known sea level). Analogical storm broke in 2001 November 1, but the sea level was a bit lower $(128 \mathrm{~cm})$ at the time. In 2001-2002 from December till February there were 7 more cases when the wind speed in gusts exceeded $28 \mathrm{~m} / \mathrm{s}$. January in 2007 must be outlined too because the sea level exceeding $100 \mathrm{~cm}$ or close to it was registered as permanent for two weeks. This was the maximum such as duration since the beginning of observations. Recurrence of strong storms or hurricanes within the last decades is presented in Fig. 3, which shows the slight increase of stormy activities according to the annual number of three-hour wind observation cases when the velocity exceeded $24 \mathrm{~m} / \mathrm{s}$ at the Lithuanian nearshore at Klaipeda

During relatively mild winters frequent thaws exchanged with frosts occur which results in favourable conditions for suffosion processes on moraine coasts, which occupy 4.5 kilometers long strip of the seashore. When maximum annual sea level gauge readings are compared to minimum and mean data it clearly shows a constantly increasing trend. During the last 20 years it has been increasing extremely rapidly (Fig. 4).

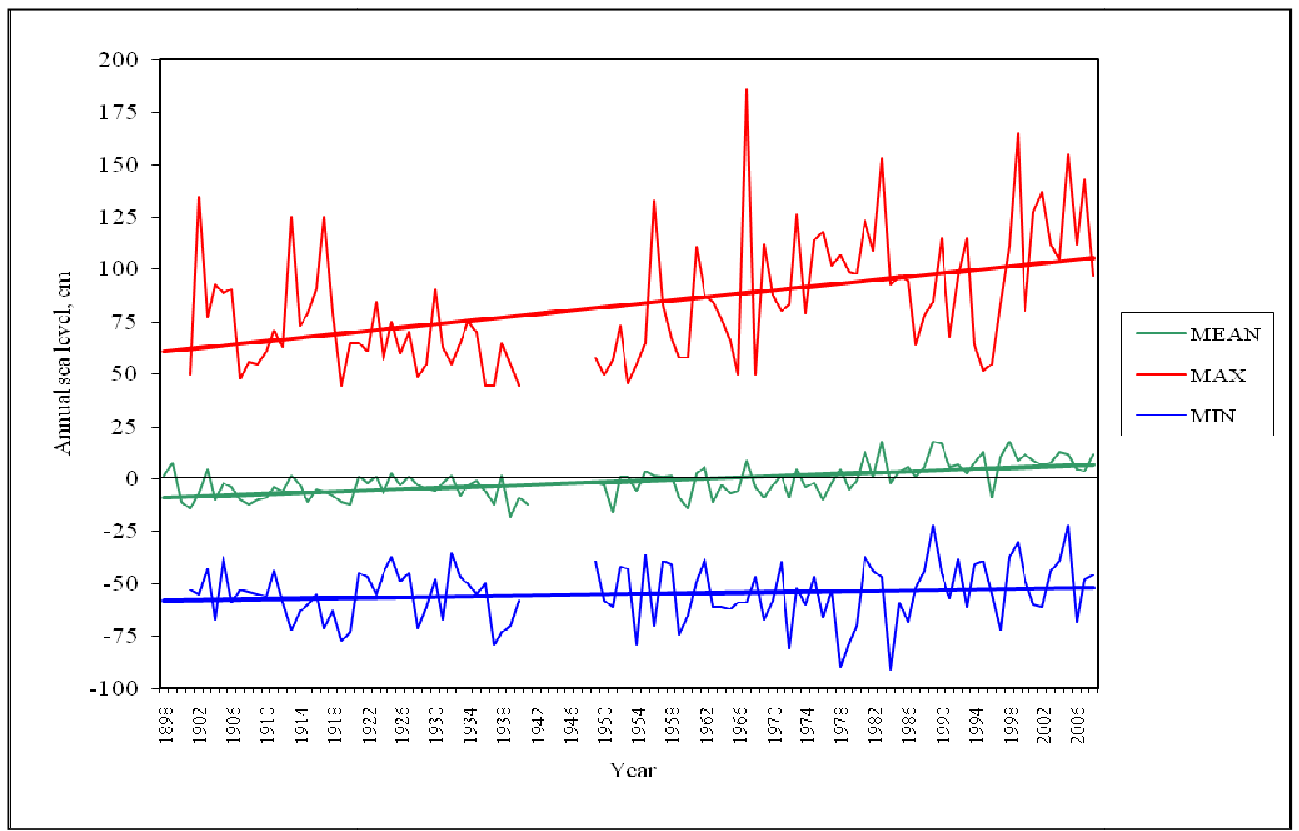

Fig. 4. Annual sea level trends in the Baltic Sea at Klaipeda. 
During the hurricane Anatoly the mainland coast lost 30 hectares of the protective dune or the coastal slope. The worst damages were recorded near Palanga, where over 20 meters of the protective dune were swept away and the promenade pier was even separated from the land. Hydrotechnical constructions protected the dunes from damages near Klaipeda (mainland part) and Šventoji. During Gudrun, the seashore near Palanga again suffered the greatest loss (10 meters) in comparison to other places. Even the slopes covered with tree branches were swept away. During the strong storm the loss of the coast reached 7 hectares and almost 3 hectares were added by holiday makers, who destroyed plant cover, treaded paths and encouraged sand slides from steep slopes. In 2001-2002 during storms another 10 meters of the protective dune were swept away, and the sea shore lost 5.2 hectares. Even during 2003-2004, which were considered to be comparatively calm from the meteorological point of view, 2 hectares were lost. What is more, because of suffosion 1.52.5 meters of moraine shores are lost yearly. In the previous 6 years 41 meters of the protective dune were lost 1 kilometer southwards from Palanga. In 1999-2009 the continental part of the coast lost about 50 hectares of the protective dunes. It is only near border with Latvia where the foresters step by step are reconstructing the protective dune which was dug off when installing the oil terminal pipeline. In other places the dunes almost were not reconstructed. On the average 2 meters of the protective dune or the coastal slope are washed away during a year (Fig 5).

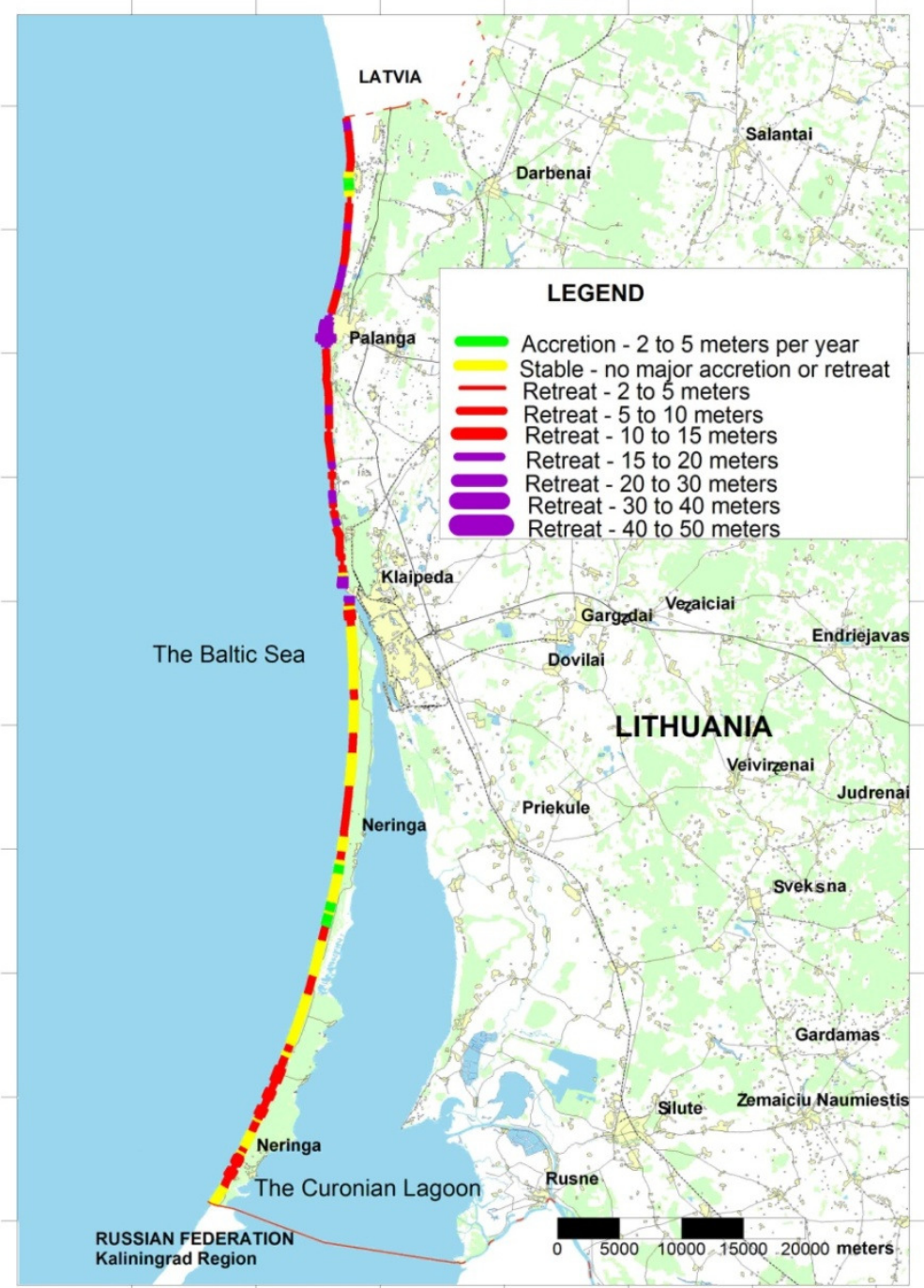

Fig. 5. Changes of the Lithuanian coast of the Baltic Sea in 1999-2009 
The Curonian Spit seashore lost 25 hectares of the protective dune during the hurricane Anatoly. All the shore was abraded, but the largest area was washed away was in the northern part of the Curonian Spit within the impact of jetties of the Port of Klaipeda. During Gudrun there suffered only separate belts of the shore, mostly the northern point and some other quite scattered sites. 6.5 hectares of the restored bottom of the slope were lost mainly, but by the end of the year most of the damaged belts recovered and the loss made only 2 hectares. In 2001-2002 storms took away 4.2 hectares of the protective dune. During every following calmer year the western slope grew by 2-5 hectares. It was due to tree branch coverings arranged by foresters and due to plant coverage. All in all, in 1999-2009 36 hectares were washed away ( 0.7 meters on the average a year), but 13.5 hectares of the shore recovered, and the total loss was only 22.5 hectares (Fig. 5). Changes of similar order were recorded on the Latvian seashore to the north from Lithuania (Eberhards et al. 2006, 2008).

\section{Discussion}

The period of 1999-2009 was rather stormy, cases of very high water level were observed quite frequently. Hurricanes Anatoly and strong storm Gudrun raged. Several more gales almost as strong as hurricanes came. The sea shore experienced mighty stress because of wind, wave and current activities. Though the entire Lithuanian seashore was attacked by the equal force, the mainland and peninsula parts of it suffered damages of different scales. Curonian Spit seashore southwards from the Klaipeda Strait, even with no hydrotechnical constructions on it, was better prepared to withstand storms and inroad crowds of holiday makers. Whenever a focus of abrasion appeared there, it was immediately covered with tree branches in order to hold sand in dunes. At the same time the situation in the continental part of the sea shore was different from that one in the Curonian Spit, especially near Palanga. When in 1997-1998 the groyne was under the promenade pier, it was pulled down being very easy for winds and sea waves to affect the protective dune. After foresters were removed from taking care of the mainland seashore, this zone received less concern by far. Only separate belts were properly enforced, however the major part of the seashore was constantly under the impact of holiday makers. 


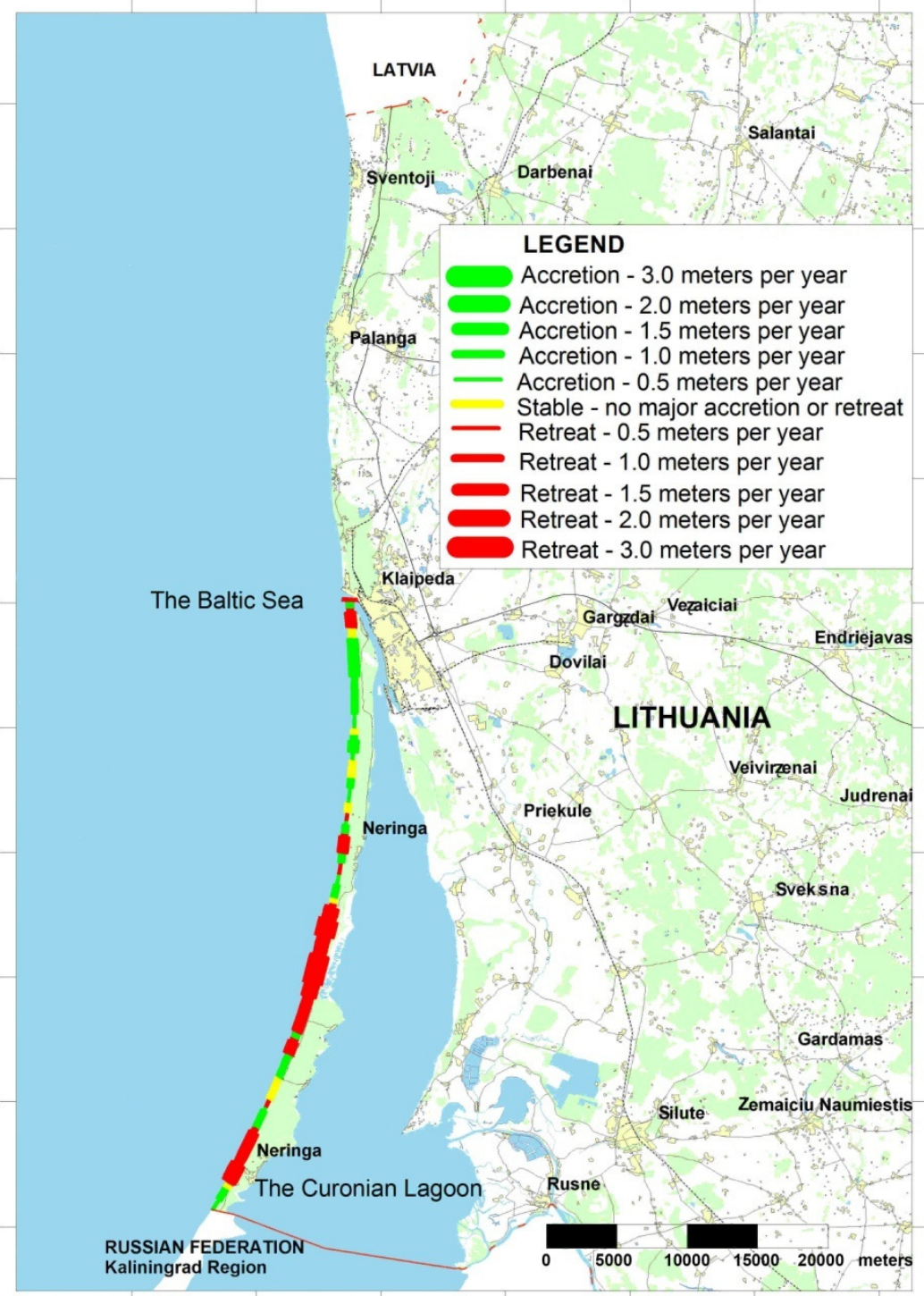

Fig. 6 Trends of changes of the western slope of protective dune of the Curonian Spit in 1859-1910 (according to the historical data from Gudelis, 1999)

Mainland seashore endures great stress because of anthropogenic activities, too. During the period of exploration the protective dune that is 1 kilometer to the South from Palanga pier narrowed by 41 meters. Since pulling down of the groyne some 10-15 meters have been lost in addition. After arranging a stone bar (twice as short as the former groyne) in the middle of 2005 the situation improved to some extent, but the reliability of the stone bar will be verified by future hurricanes. Shore protection means are applied irregularly. Great amounts of stones, gravel and shingle are illegally taken out from the beaches for house building and other needs. Constant deterioration of the former port of Šventoji jetties can form a new area of abrasion in the nearest future. During the strong storm Gudrun water streams started flowing over the jetties. In future the present widest beach (120 meters) on the Lithuanian coast can became narrower. Great damages to Lithuanian sea coast are made during summer periods, when more and more dunes are trodden by their visitors and later by the winds. Average retreat rate of the protective dune for the Curonian Spit in 1859-1910 was about $60 \mathrm{~cm}$ (Fig. 6), but in 1999-2009 it occurred to be almost the same (referring to Fig. 5). 
The seashore that lies in the former military zone is being very badly abraded. It had been not enforced before numerous undisciplined holiday makers began to visit it frequently. Nowadays only 5 percent of the western slope of the protective dune is covered by plants. Such cover is too weak to stabilise the sand. Holiday makers destroy the plant cover and cause sand slides from steep dunes after storms, thus enabling the sand to move under the influence of wind. The wind carries sand further from the coastline to the fields causing its shortage on the beaches. It's necessary to remember how well the areas of dunes near Palanga and Melnrage were planted with Daphne-willows (Salix daphnoides) and other bushes after the hurricane in 1967. After the reconstruction of the Klaipeda port jetties, processes of the shore abrasion became more intensive near to the north from Klaipeda. Only on separate fragments of the shore as near Šventoji and Palanga, a protective dune was constructed to hold and accumulate the running sand. On the rest of the shore after partial washing off or almost entire destroying of the protective dune, westerly stormy winds transport the sand and scatter it on the fields. The running sand doesn't meet any obstacles on its way there, as it has happened on the Curonian Spit. Thus it could be said that sand transportation abilities on the mainland seashore depends more on the wind than on man. Sand is also transported by near-the-shore currents. According to the long term investigation data, at the horizon of 15 meters (depth 20 meters) in normal weather conditions $55.3 \%$ of near-the-shore currents go to the north, $35.7 \%$ hold the south direction, and only $5.7 \%$ of near-the-bottom currents are directed to the shore, 3.3\% go seawards. Consequently when eastern or northern winds blow 5 to 10 percent of currents are directed towards the coast (Dubra, 2003). It was counted that according to the sand transportation observation experiments from the Palanga promenade pier 123 thousand cubic meters of sand were transported to the north and 23 thousand cubic meters - to the south in 2005.

At the end of the $19^{\text {th }}$ century along the Curonian Spit seacoast a 5-14 meters high and at places reaching 100 meters wide protective foredune appeared as a result of the work of waves, wind and human hands. This construction is planted with long-rooted plants and its eastern bottom (dune toe) boasts pines in order to prevent the sea outcast sand from spreading all over the spit. At present this magnificent construction is constantly being covered with tree branches which together with plants hold back the sand cast by the sea. After World War II foresters enforced this construction with long rooted plants. Marram grass (Ammophila arenaria) is planted on 1.5-2.2 kilometer long belts of the protective foredune on western slope every year. Currently the western slope of the protective dune has $30 \%$ plant coverage which stabilises the sand on the dunes, protects rather well the western slope from wind attacks and a bit less from wave abrasion. After washing off the slope the roots of this grass produce root suckers and sprouts which hold the sand, and ridges of the sand start forming at the bottom of the protective foredune. Marram grass is a halophyte plant. Usually it covers only the western slope, it's seldom found on the summit of the dune, that's why it doesn't bother holiday makers. Sharpish stalks endure well trampling it down or covering with sand, thus it helps to accumulate a lot of sand. By the way, holiday makers try to avoid this sharp stalked plant and prefer arranged paths and stairs. The western slope of the protective dune on the Curonian Spit looks like a meadow ready to withstand covering up with drifted sand. Many scientists in non European countries (Goldsmith, 1985) and in a number of European ones (Janssen, 1995; Buck, 1995) consider Marram grass to be the most convenient plant for fixing sand. In order to widen the nutrient base for these plants it is applicable to grow Beach pea (Lathyrus maritimus) together with Marram grass. Besides these plants, Maritime peavine (Leymus arenarius), Tall gypsophila (Gypsophila paniculata), 
Sea sandwort (Honckenya peploides) and some other long rooted plants are planted on the dune ridges and slopes. Rugosa rose (Rosa rugosa) with red, white fragrant blooms is very decorative and adorns the dune ridges. In the places frequently visited by holiday makers the dune ridges are planted with Daphne willows. They do both: fix the sand and protect the holiday makers from wind. The vegetation growing on the western slope of the protective foredune result to the slope growth by 0.1-0.2 meters yearly. According to the Lithuanian example, it's a pity that 90 percent of phyto-technological reinforcement arrangements and repair works are performed in the most frequently visited places and on more intensively abraded areas while the rest of the seashore receives by far less concern. Otherwise it could be possible not only to reinforce the coastal zone, but also to create nice looking plant compositions, which would attract tourists.

\section{Conclusions}

Hurricanes and strong gales with the sequent high sea level often devastate the sandy Lithuanian sea coast. According to the changes, which are evident from long-term hydrometeorological data, it must be mentioned that Lithuanian coastal area will suffer more significant abrasion of the coast in the future. In the case of the Curonian Spit the measures should enable accumulation of the drifting sand within the impact of the strong wind of southwesterly directions. Attempts to stabilise the seashore last from ages ago till nowadays. The results of this process are especially evident when comparing the degraded dune area immediately after the strong storm or hurricane to the renewed dune. Comparison of the trends of the accretion or retreat rate of the protective dune on the Curonian Spit showed that the present figures look similar to those at the end of $19^{\text {th }}$ century or the middle of $20^{\text {th }}$ century. Average retreat rate of the protective dune for the Curonian Spit in 1859-1910 was about $60 \mathrm{~cm}$, but in 1999-2009 it occurred to be almost the same. Due to local hydrodynamical situation which is marked out by forced sea level rise near the southern jetty it is necessary to implement additional hydrotechnical structures which would be helpful in forming the protective dune ridges there. By applying complex measures including tree branches and different plants in the dune zone of the Curonian Spit it was achieved that protective dune can reach accumulation rate of 0,2-0,7 meters yearly. European beach-grass or Marram grass (Ammophila arenaria) is considered among the best halophyte plants for the stabilisation of the dune environment. The most important thing in the restoration of the most eroded parts of the protective dune is the formation of the foredune ridge not directly at the dune slope, but keeping some intercept distance.

\section{References}

Buck A. L. 1995. The Habitats Directive: Coastal and Marine Habitats and Species of the Atlantic Biogeographical Region. In: Healy M. G. and Doody J. P. (Eds.) Directions of the Coastal Management. Cardigan, 37-45.

Daujotas M. 1958. Planting of marine coastal sandy areas. Vilnius, 232 p. In Lithuanian.

Dubra J. 2003. Oil rig at Nida and its possible impact to the environment In: State of the environment of the Baltic Sea. Kaunas, 111-114. In Lithuanian.

Dubra V., Grecevičius P. 2006. Stabilization of the Sandy Coast: an Example of the Curonian Spit in Lithuania. In: Coastal Dynamics, Geomorphology and Protection. Selected papers of the Eurocoast-Littoral 2006, Gdansk, 180-188. 
Dubra V. 2006. Influence of hydrotechnical structures on the dynamics of sandy shores: the case of Palanga on the Baltic coast. Baltica, 19 (1). Vilnius, 3-9.

Eberhards G., Lapinskis J., Saltupe B. 2006. Hurricane Erwin 2005 coastal erosion in Latvia. Baltica, 19 (1). Vilnius, 10-19.

Eberhards G., Lapinskis J. 2008. Processes on the Latvian coast of the Baltic Sea: Atlas. Riga. 63 p. In Latvian and English.

Goldsmith V. 1985. Coastal Dunes. In: Davis R. A. (Ed.) Coastal Sedimentary Environments. New York, Berlin, Heidelberg, Tokyo, 303-378.

Gudelis V. 1998. The Lithuanian Offshore and Coast of the Baltic Sea. Vilnius, 444 p. In Lithuanian.

Janssen M. P. 1995. Coastal Management: Restoration of Natural Processes in Foredunes. In: Healy M. G. and Doody J. P. (Eds.) Directions of the Coastal Management. Cardigan, 195-198.

Karwowski S. 1913. Palanga and Kretinga. Poznan. In Polish.

Knaps R. 1966. Sediment transport it the coastal area of the Eastern Baltics. In: Development of marine coasts within the conditions of fluctuation movements of the Earth crust. Tallinn, 21-29. In Russian.

Kriaučiūnienè, J., Gailiušis, B., Rimavičiūtè, E. 2006: Modelling of shoreface nourishment in the Lithuanian nearshore of the Baltic Sea. Geologija, 53, 28-37.

Žilinskas G., Jarmalavičius D., Kulvičienè G. 2000. Assessment of the effects of hurricane Anatoly on the Lithuanian marine coast. Geographical Yearbook, 33 (1). Vilnius, 191-206. In Lithuanian.

Žilinskas G., Jarmalavičius D., Minkevičius V. 2001. Aeolian processes on the marine coast. Vilnius, 283 p. In Lithuanian.

Žilinskas G., Jarmalavičius D. 2003. Trends of Lithuanian sea coast dynamics. Geographical Yearbook, 36 (1). Vilnius, 80-88. In Lithuanian. 